\title{
Performance of ANN for rainfall-runoff prediction
}

\author{
S. K. Kothe, B. L. Ayare, H.N. Bhange, S.B. Nandgude and D. M. Mahale
}

Received : 05.01.2019; Revised : 20.02.2019; Accepted : 11.03 .2019

See end of the Paper for authors' affiliation

Correspondence to :

\section{B. L. Ayare}

Department of Soil and Water Conservation Engineering, College of Agricultural Engineering and Technology, Dr. Balasaheb Sawant Konkan Krishi Vidyapeeth, Dapoli (M.S.) India
- ABSTRACT : The use of artificial neural network is becoming increasingly common in the analysis of hydrology and water resource problems. In present study, the observed rainfall and runoff data of four years $(2010,2011,2013$ and 2014) were used as input data. In ANN, input data was divided in three segment 70 per cent, 15 per cent and 15 per cent for training, validation and testing purpose, respectively. Rainfall-runoff relationship is an important component in water resource evaluation and therefore, the predicted runoff of 70 numbers of different types of model was tested statistically with observed runoff using statistical parameter, i.e. root mean square error (RMSE), mean absolute error (MAE), co-efficient of determination $\left(\mathrm{R}^{2}\right)$ and correlation (r). This study showed that out of 70 ANN architectures, ANN architectures 1-48-1 could be adopted to estimate runoff from ungauged watershed with rainfall as input.

- KEY WORDS : ANN, Rainfall-runoff modeling, Co-efficient of determination, Correlation

- HOW TO CITE THIS PAPER : Kothe, S.K., Ayare, B.L., Bhange, H.N., Nandgude, S.B. and Mahale, D.M. (2019).Performance of ANN for rainfall-runoff prediction. Internat. J. Agric. Engg., 12(1) : 112-117, DOI: 10.15740/HAS/IJAE/12.1/112-117. Copyright@2019: Hind Agri-Horticultural Society. 